\title{
En særegen form for oppmerksomhet
}

\author{
Melanie Fieldseth
}

\begin{abstract}
In this article I take a closer look at the work of Mette Edvardsen and Morten Traavik. Their respective bodies of work have little in common in artistic terms, yet both have generated public debate. Rather than being based on informed, critical engagement with the work and practice of these artists, the debate has largely questioned the value of what they do and the public funding that supports it. I see this debate as a reminder of how art necessarily acts or works within contexts, and of the need for qualified insights into how it does so. Within the performing arts, scholars have been thinking about concepts of autonomy and heteronomy and how they might contribute to understanding different practices and experiences of contemporary performing art. These ideas inform this article, which examines the work and practice of Edvardsen and Traavik with an emphasis on aesthetic, dramaturgical and contextual perspectives.
\end{abstract}

Keywords: Dramaturgy, autonomy, heteronomy, Mette Edvardsen, Morten Traavik

\section{Om forfatteren}

Melanie Fieldseth arbeider som skribent, dramaturg og med forsknings- og utredningsoppdrag. Hun har vært scenekunstkonsulent i Norsk kulturråd, der hun i perioder har vært tilknyttet FoUseksjonen. På oppdrag fra Kulturrådet skrev hun Fri scenekunst i praksis, et kunnskapsprosjekt om den frie scenekunstens utvikling i Norge. Hun har vært dramaturg på Black Box teater og medredaktør i tidsskriftet 3 t. Som skribent har hun bidratt til forskjellige fagpublikasjoner og har $\mathrm{i}$ tillegg virket som kritiker. Fieldseth har hovedfag i teatervitenskap fra Universitetet i Bergen. Hun arbeider med en bok om historien til Teaterhuset Avant Garden som forventes utgitt i 2020.

msfieldseth@gmail.com

Teatervitenskapelige studier 2019 (C) Melanie Fieldseth

Nummerredaktører: Anette Therese Pettersen og Elisabeth Leinslie

Medredaktør: Julie Rongved Amundsen. For TVS: Ragnhild Gjefsen

Ansvarlig redaktør: Tor Bastiansen Trolie - tor.trolie@,uib.no

Publisert av Teatervitenskap, Institutt for lingvistiske, litterære og estetiske studier, Universitetet i Bergen

Bergen Open Access Publishing - https://boap.uib.no/index.php/tvs

ISSN: 2535-7662

Manusutviklingen av disse artiklene er støttet av: Danse- og teatersentrum, Norsk Kulturråd, Kristiansand kommune, Fritt Ord, BIT teatergarasjen, Dramatikkens hus, Bergen kommune. 


\section{En særegen form for oppmerksomhet}

\section{Innledning}

«For meg handler det også alltid om å skape en opplevelse som publikum, eller leseren, skal kunne ta del i og omskape til sin egen.» ${ }^{1}$ Mette Edvardsen

«Folk får selv vurdere om det er ren kunst, eller en politisk performance. Det er ikke noe som er rett og feil.» ${ }^{2}$ Morten Traavik

Hvordan kan scenekunst virke i verden som kunstneriske handlinger? Dette er et kjernespørsmål i en tid hvor kunstens rolle i samfunnet er satt under debatt. Med hensyn til fri scenekunst dreier debatten i norsk sammenheng seg ofte om bruken av offentlige midler til å støtte ny kunstproduksjon, om denne kunsten er riktig bruk av skattekronene, og ellers viktig nok til å løftes inn i det offentlige ordskiftet gjennom omtaler og kunstkritikk i allmenne medier. Det handler med andre ord om kulturpolitiske og verdimessige standpunkter. I et slikt klima for offentlige ytringer kan det være trangt om plassen. Nærgående analyser av hvordan et kunstnerisk arbeid er bygget opp, og hvordan det virker i møte med publikum og omverden, kan tape terreng. Men det er nettopp i slike analyser at interessante svar kan ligge. ${ }^{3}$

I 2017 gjorde Sløseriombudsmannen sin inntreden i det offentlige ordskiftet om fri scenekunst. Den selvtitulerte, anonyme ombudsmannen har fattet interesse for en rekke kunstnere, men særlig Mette Edvardsen ble gjenstand for en uinformert og feilinformert vrede drevet frem av en ideologisk uenighet om bruken av offentlige midler. ${ }^{4}$ Det er selvfølgelig ikke første gang kunstnere som mottar offentlig tilskudd, blir kritisert på verdimessig grunnlag. I senere år er trolig Morten Traavik blant kunstnerne som har fått flest oppslag på grunn av et oppsiktsvekkende og tidvis kontroversielt virke. ${ }^{5}$

Utenom å motta offentlig tilskudd er det tilsynelatende lite som forener arbeidet til disse to kunstnerne. Edvardsen beskriver seg selv som en utøver. Hun tar utgangspunkt i dans og koreografi og er opptatt av scenekunst som praksis og situasjon. ${ }^{6}$ Traavik presenterer seg som regissør og kunstner hvis arbeid med iscenesettelse fremhever identitet som rollespill, og utfordrer grensene mellom kunstneriske uttrykk og en aktivistisk holdning til samfunnsmessige problemstillinger. ${ }^{7}$ Den lavmælte Edvardsen og den høylytte Traavik fremstår svært ulike som kunstneriske personligheter, samtidig som de begge to er sterkt tilstedeværende i sin kunst. De har til felles at kunstproduksjon inkluderer flere medier og materielle uttrykksformer enn sceneforestillinger alene, for eksempel bøker, video/film og objekter. De arbeider imidlertid med vidt forskjellige formspråk, formater og tematiske interesser, og de forholder seg til forskjellige kunstneriske og sosiale kontekster i sitt virke. De tar utgangspunkt i forskjellige kunstneriske tradisjoner - henholdsvis dans/koreografi og teater, og knytter an til ulike kunstneriske diskurser. 
Den verdimessige kritikken som er blitt rettet mot arbeidet til Edvardsen og Traavik, blander en kunstnerisk, kvalitetsmessig dom sammen med en ideologisk motivert fordømmelse. ${ }^{8}$ Man kan være både faglig og prinsipielt uenig i premissene som legges til grunn for kritikken, men denne typen mottakelse er like fullt en påminnelse om at scenekunst ikke er en isolert størrelse. Et kunstnerisk arbeid er en aktiv handling som virker innenfor en samfunnsmessig kontekst.

Påminnelsen om at kunsten står i en dynamisk relasjon til samfunnet, motiverer denne artikkelen. Med fraspark i den verdimessige kritikken av Edvardsen og Traavik byr den på en estetisk og dramaturgisk lesing av aspekter ved deres respektive kunstnerskap. Ikke for å argumentere mot eller forsøke å forstå kritikken, men for å komme tettere på hvordan disse kunstnerskapene agerer. Edvardsen og Traavik benytter virkemidler og grep i sitt kunstneriske arbeid som krever ulike lesemåter, og arbeidet vil følgelig analyseres på ulike nivåer. Mens beskrivelser av forestillinger og forestillingselementer gir innsikt i Edvardsens virke, er samspillet mellom arbeidsmåte, kontekst og medial fremstilling en sentral dimensjon hos Traavik. En estetisk og dramaturgisk lesing er også en subjektiv tolkning, men argumentasjonen som benyttes i denne artikkelen, tilstreber en faglig forankret analyse av disse kunstnerskapene.

\section{Handlinger og virkninger}

Når jeg presiserer at det spørres etter scenekunstens virkninger i kraft av å være kunstneriske handlinger, er det for å skjerpe blikket på egenskapene og elementene som utgjør et kunstnerisk arbeid, og hvordan disse agerer i møte med publikum og omverden. Et kunstnerisk arbeid kan i denne sammenhengen referere til noe avgrenset, for eksempel en forestilling, eller til en kunstners eller kunstnergruppes virke $\mathrm{i}$ betydning arbeidsmåter, overordnede valg eller posisjoner som kunstneren eller gruppen anvender eller inntar. Et utvidet begrep om dramaturgi som favner over både forestillingen og dens omgivelser, kan bidra til å belyse hvilke relasjoner og sammenhenger scenekunsten både skaper og virker i.

Dramaturgi er ikke blot en fortællemåde eller den enkelte forestillings struktur, men også den interaktion, som et teater skaber med publikum og omverden. Et teater kan interagere med sit publikum, sin by og med medierne på mange forskellige måder og skabe en anden form for opmærksomhed på politiske, sociale og æstetiske forhold. ${ }^{9}$

Denne måten å tenke dramaturgi på anerkjenner at flere typer kontaktflater mellom kunst og omverden er virksomme i og rundt et kunstnerisk arbeid. Scenekunstens mulighet til å skape en særegen form for oppmerksomhet på bestemte forhold innebærer at det kunstneriske arbeidet trer frem, og henvender seg til publikum og omverden på spesifikke måter. Samtidig forutsettes det en interaksjon eller vekselvirkning, slik at konteksten for scenekunstens henvendelse også kan sies å være meningsbærende.

Forholdet mellom kunst og kontekst kan ses i sammenheng med hvordan begrepene autonomi og heteronomi er blitt gjenstand for faglig drøfting, og gis nye nyanser i møte med forskjellige kunstuttrykk. Sosialt engasjert kunst og kunstuttrykk som forutsetter deltakelse eller handling hos publikum, er eksempler på uttrykksformer der slike diskusjoner kan oppstå. Hensikten med å 
sette disse begrepene opp mot hverandre er å vise hvordan kunstens sammenhenger kan betraktes som en del av, snarere enn atskilt fra, kunstverket.

Særlig i forbindelse med studier av scenekunst for barn og unge finnes det en interesse for å undersøke kunstuttrykk i et spenningsfelt mellom det autonome og det heteronome. To eksempler fra nyere faglitteratur åpner begrepenes bruksmåter:

Med autonom kunst forstår vi gjerne verk absolutt adskilt fra formidlingskontekst og publikum; det autonome verket er et verk i kraft av sin abstraksjon av materiale og adskillelse fra formidlingskontekst og publikum. Med heteronom kunst forstår vi gjerne verk som på ulike måter undersøker sin institusjonelle, arkitektoniske, sosiale og mediale kontekst, og derigjennom også undersøker og eventuelt endrer sine verkegenskaper og publikums status som betrakter på utsiden til deltaker. Det heteronome kommer til uttrykk gjennom hvordan materiale bearbeides gjennom produksjonsstrukturene, $i$ relasjonen mellom verk og publikum og i det romlige. ${ }^{10}$

[Shannon] Jackson bruker begrepene autonomi og heteronomi på denne måten: "[...] the etymology that seems most helpful is the one that aligns 'autonomy' with 'the condition of being self-governing' and 'heteronomy' with 'the condition of being governed by an external rule" (Jackson, 2008, s. 140). Denne definisjonen fristiller autonomibegrepet fra den modernistiske forståelsen av det, og åpner isteden for dobbeltperspektiv som gjør det mulig å anerkjenne kunst som en egen erkjennelsesform og samtidig forstå og fortolke kunsten i relasjon til den konteksten den er produsert $i^{11}$

Kanskje er det nettopp i disse områdene av kunstlandskapet at refleksjon over kunstens autonomi og heteronomi er særlig skarp. Kunstproduksjon for barn og unge kan tenkes å komme raskt $\mathrm{i}$ berøring med perspektiver på læring, formidling og hva som er relevant $\mathrm{i}$ livsverden til de unge. Samtidig drøfter denne faglitteraturen teorier og fenomener som i stor grad tilhører samtidens utøvende kunst mer generelt.

Begge eksemplene unngår det man kan kalle heteronomibegrepets skyggeside, nemlig tilknytningen til instrumentelle målsettinger, der kunst «reduseres til effekt og målbare resultater» ${ }^{12}$ eller underlegges eksterne betingelser og logikker som svekker muligheten til å ta kunstneriske valg. Isteden ser man forsøk på å holde fast ved kunstnerisk autonomi, men uten å isolere kunstens tilblivelse, virkninger og relasjon til publikum fra dens kontekst. Musikkforsker Astrid Kvalbein byr på en annen vri på spenningen mellom det autonome og heteronome. Hun skriver om muligheten for en estetisk form for heteronomi som springer ut av tanken om at, $\mathrm{i}$ hennes tilfelle, musikken «aldri har 'rein' mening» og går inn i et spill med andre elementer, dens omgivelser og til og med kontekster som er tilknyttet andre kunstfelt enn musikkens eget. ${ }^{13}$

Et utvidet begrep om dramaturgi, Kvalbeins formulering om estetisk heteronomi og diskusjonen om autonome og heteronome perspektiver på scenekunst, peker i retning av mer sammensatte forståelser av forholdet mellom kunst og kontekst. I et essay om performativitet omtaler scenekunstforskeren Shannon Jackson den performative dimensjonen ved utøvende kunst på følgende måte: «[...] the reality-making capacity of the performative happens in the moment of a receiver's 'uptake'. A world is made in that exchange.» ${ }^{14}$ De estetiske og dramaturgiske 
egenskapene ved et kunstnerisk arbeid er med på å skape premissene for hvordan det møter omverden eller, i Jacksons terminologi, inngår i en utveksling. Listen over elementer som åpner opp flerfoldige estetiske og dramaturgiske muligheter er gjenkjennelig: tid og rom, intensitet og skala, materialitet og medier, utøverens rolle og tilnærming, kropp og bevegelse, graden av abstraksjon, forhold til fiktive og sosiale virkeligheter.

\section{Praksisens estetikk}

«I am I Am a Cat by Soseki Natsume.» Jeg sitter på en av de brede avsatsene som skaper et lite, tilbaketrukket område i et ellers stort og luftig rom i Galerie Ravenstein, en historisk bygning i sentrum av Brussel som til daglig rommer kontorlokaler, butikker og spisesteder. Ved siden av meg sitter dansekunstneren Mette Edvardsen som nettopp har presentert seg. Edvardsen er en levende bok, og jeg er en lyttende leser. Rommet med de store vinduene som vender mot byggets storslåtte interiør, er, i anledning festivalen Kunstenfestivaldesarts 2017, omgjort til leserommet til Time has fallen asleep in the afternoon sunshine.

Time has fallen asleep in the afternoon sunshine er et prosjekt utviklet av dansekunstneren Edvardsen, men slik det ble omtalt av Time Out London i 2012, er det: «[...] not really a dance piece at all». ${ }^{15}$ Prosjekttittelen avslører en litterær tilknytning. Tittelen er en setning tatt fra et essay av Alexander Smith, slik den er sitert i Ray Bradburys roman Fahrenheit 451. Romanen gir en dystopisk skildring av en fremtid der underholdning og trivielle sysler svekker menneskets kunnskapstørst og kritiske refleksjon. Bøker er forbudt, og brannvesenets oppgave er å håndheve forbudet ved å finne og brenne alle bøker som er forsøkt gjemt unna. En motstandsgruppe har imidlertid flyktet til skogen. Gruppen har tatt på seg oppgaven av å bevare en bok hver ved å lære den utenat og dele den videre med kommende generasjoner.

Lik menneskene i skogen i Bradburys roman har Edvardsen og de medvirkende utøvere valgt seg en bok å lære utenat. Sammen utgjør de et levende bibliotek. Når dette biblioteket åpnes i forbindelse med en festival, fungerer det i stor grad etter et gjenkjennbart utlånsprinsipp. Publikum får oversikt over hvilke bøker som er tilgjengelige og når, og individuelt bestiller de den de ønsker seg. Tilskueren (betegnelsen brukes her i mangel på noe mer presist) møter opp til avtalt tid, som regel er prosjektet faktisk lokalisert $i$ et eksisterende bibliotek, og - i en liten vri på den sedvanlige utlånssituasjonen - blir hentet av boken sin og ledet bort til et rolig sted for lesing.

Bøkene, eller utøverne, er lånt og lest av tilskuerne, eller rettere sagt leser bøkene seg for tilskuerne. Utøveren utsier boken sin så langt hun har lært den, og så langt utlånstiden tillater. Som leser kan det hende man får en relativt nyslått bok som arbeider med å få ordene under huden. Eller kanskje en mye lest utgave der ordene er lagret et sted dypt i utøverens kropp. For utøveren er lesingen en forlengelse av prosessen med å lære seg boken, slik utøveren Bruno De Wachter, som har vært en del av prosjektet i flere år, forklarer: «Time has fallen asleep in the afternoon sunshine is a project of indefinite duration and the practice is not so much a preparation for a performance as a goal in itself. The lending moments during the festivals give the public an insight into that practice. ${ }^{16}$ 
Lesingen er en del av en kontinuerlig praksis av å memorere og dele det som er memorert. De Wachter beskriver en situasjon der publikum møter en manifestasjon av denne praksisen. Lesesituasjonen kan derfor betraktes som et utsnitt av noe pågående, et segment av et tidskontinuum som deles mellom utøveren og tilskueren. Å gi praksisen forrang og gjøre den til selve den kunstneriske handlingen eller forestillingen, innebærer ikke ved første øyekast en fundamental endring av premissene for forholdet mellom utøver og tilskuer. Det er fremdeles utøveren som gjør noe, og tilskueren som tar imot det som gjøres. Samtidig åpnes det for grader av sosial interaksjon mellom dem, særlig i forkant og etterkant av lesingen. Tilskueren har også en viss grad av medbestemmelse over sin fysiske plassering og atferd i relasjon til utøveren.

De Wachter skriver at praksisen er et mål i seg selv, snarere enn å være forberedelse til forestillingen. Hva betyr det å dele en praksis med publikum? Hva er den virkelighetsskapende kapasiteten i en slik situasjon? Hva er det utøveren gjør?

The task of the performer does not consist in facilitating the book's understanding and allowing for its transformation into decipherable signs that give an orientation to the reading for the audience, but in giving the book a body that takes it in, creating a reading that is detached from dramatization.

\section{$[\ldots]$}

The task of memorizing a book cannot consist only of acquiring some external contents by inserting them into one's own memory, without further consequences. It necessarily implies embodying the contents, which means that the linguistic matter mixes, melts, and integrates with the whole physical and psychic functioning of the person, intermingling with their experiences, altering their remembrances as well as their way to remember, changing their language and their way of reading. ${ }^{17}$

Scenekunstforskeren Victoria Pérez Royo beskriver, i overnevnt sitat, hvordan lesesituasjonen som skapes i dette prosjektet, har lite å gjøre med formidling av litteratur eller det å gi tilskueren en innholdsmessig eller ekspressiv leseopplevelse. Det handler om å stille til skue en form for kroppsliggjort erfaring.

Både Royo og De Wachter peker på de formmessige forholdene prosjektet etablerer, og hvordan disse påvirker tilskuerens opplevelse. Det finner sted utenfor teatrets scenerom, ofte et sted som forbindes med bøker. Utøveren og tilskueren deler dette rommet, og den sosiale relasjonen mellom dem kan til en viss grad formes av begge partene. Disse forholdene skaper oppmerksomhet på lesing som en kroppslig og kognitiv handling. Royo og De Wachter skiller mellom en intensjon om å formidle bokens innhold, og om å invitere tilskueren til et nært møte med den kroppsliggjorte praksisen av å lære boken utenat. En praksis som i Royos analyse er transformativ for utøveren, idet bokens innhold blander seg med utøverens språklige vaner, og personlige minner og erfaringer. Det hun beskriver som en lesing forankret i kroppen og frakoblet dramatisering, klinger godt med De Wachters beskrivelse av å dedikere seg til en praksis som et mål i seg selv, også i møte med publikum. 


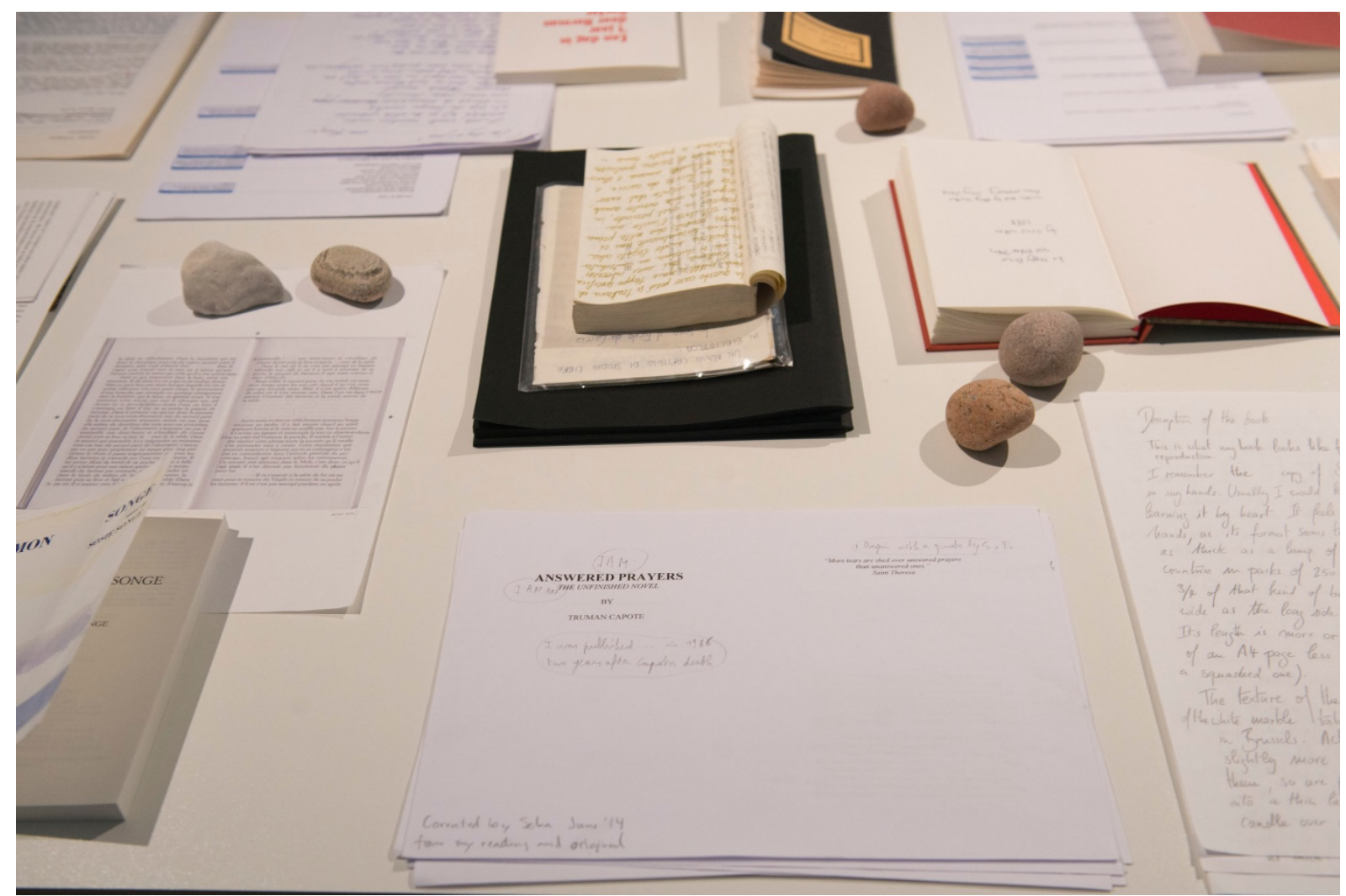

Figur 1. Time has fallen asleep in the afternoon sunshine av Mette Edvardsen på Kunstenfestivaldesarts 2017. Foto: Bea Borgers

\section{$\AA$ stille ut praksis}

Ordet «leserom» leder tankene til biblioteker, museer og arkiv som gir den besøkende mulighet til å fordype seg $\mathrm{i}$ et materiale - en bok, en gjenstand eller et historisk dokument, for eksempel ved å dedikere et rom til dette formålet. Bruken av denne termen er særlig relevant for det spesifikke oppholdet til Time has fallen asleep in the afternoon sunshine på Kunstenfestivaldesarts $i$ 2017. Siden oppstarten i 2010 på Playground Festival i Leuven, Belgia, har prosjektet utviklet seg både i bredden og i dybden. På Edvardsens webside kan man lese at prosjektet har blitt presentert trettini ganger mellom november 2010 og februar 2018. Hver presentasjon innebefatter, vel å merke, en rekke utlånsituasjoner eller lesinger. Til hver presentasjon er antallet medvirkende ulikt, men en opptelling basert på opplysninger på websiden, viser at minst femtisju utøvere har vært involvert hittil. For hvert land prosjektet besøker, knytter Edvardsen gjerne lokale utøvere til det, noe som innebærer en utvidelse av titlene i boksamlingen og at den rommer flere språk.

Det er særlig måtene prosjektets praksiser ble stilt til skue på i leserommet på Galerie Ravenstein som er av interesse her. Flere av de levende bøkene, blant annet Edvardsen selv, har dedikert seg til en ny praksis; å skrive boken sin ned på papir etter hukommelse. Dette har resultert i faktiske bokutgivelser:

This book has been written down from memory as part of the project Time has fallen asleep in the afternoon sunshine. It is not the author's original text. This book is a re-written version, 
altered by the process of memory, the practice of learning by heart, numerous recitations for different readers, and time. ${ }^{18}$

Eksemplarer av de omskrevne bøkene var tilgjengelige i leserommet. Men også selve praksisen med å skrive på nytt var gjort synlig; utstilt i leserommet var spor etter dette arbeidet $\mathrm{i}$ form av håndskrevne manuskripter og notater i glassmontere. De besøkende kunne også observere bøker som var i ferd med å ta form. Det vil si utøvere som satt ved de innbydende arbeidsbordene som var plassert i rommet, og arbeidet med nedskrivingen i overgangen fra hukommelse til papir.

Samtidig var leserommet vertskap til en annen lære- og leseprosess enn fra papirbok til menneske eller fra menneske til papirbok: det å lære en bok gjennom muntlig overføring fra en levende bok til en potensiell ny levende bok. Hvis man besøkte leserommet på riktig tidspunkt, kunne man være vitne til tilblivelsen av en ny generasjon levende bøker, det Edvardsen kaller andregenerasjonen. ${ }^{19}$ Andregenerasjonen har et annet opphav enn førstegenerasjonsbøkene ved at praksisen bygger på andre forutsetninger, en muntlig kilde snarere enn en skriftlig kilde.

Leserommet gjorde det mulig å materialisere flere lag ved de levende bøkenes praksis. I tillegg til det kroppsliggjorte biblioteket av levende bøker, var det også stilt ut papirbaserte samlinger. Langs en av veggene kunne de besøkende titte i et bibliotek over de første bøkene som ble til levende bøker, den originale boksamlingen i papirformat. Litt bortenfor kunne man stoppe opp ved skyggebiblioteket som inneholdt et utvalg av bøkene som ble vurdert, men ikke valgt. Endelig kunne man dykke ned i referansebiblioteket. Her kunne man lese essayer og artikler om prosjektet som var skrevet både fra innsiden av utøvere knyttet til prosjektet, og fra utsiden av andre fagpersoner. Man kunne lese i teoretiske verk og essaysamlinger som tok for seg minne, tid, skriving, lesing og publisering. Ikke minst kunne en bla i prosjektets nylig påbegynte kartotek. Kartoteket er tenkt å fungere som en kontinuerlig, løpende dokumentasjon av hvilke bøker som ble valgt av hvilke utøvere, hvor og når de ble lest for første gang. En siste praksis som leserommet åpnet for, var levende refleksjon. I løpet av festivalen ble det arrangert foredrag $\mathrm{i}$ leserommet med inviterte gjester. Sporene etter alle disse praksisene var hele tiden til stede i leserommet, både materielt gjennom papirbibliotekene og manuskriptene, men også som vedvarende erfaringer; praksiser som er i kontinuerlig utfoldelse.

\section{Skifte perspektiv}

Edvardsen er en kunstner som undersøker i dybden, men bare tidvis er det bevegelse som er gjenstand for undersøkelsen. Kunstnerskapet hennes settes gjerne i sammenheng med betegnelsen utvidet koreografi og mer nylig med betegnelsen post-dans. Snarere enn å definere og avgrense er disse betegnelsene ment å åpne nye mulighetsrom for praksiser og uttrykk som identifiserer seg med dans og koreografi, men ikke ved å repetere antatte dominerende posisjoner og forventninger.

In the last few years the term 'choreography' has been used in an ever-expanding sense, becoming synonymous with specific structures and strategies disconnected from subjectivist bodily expression, style and representation. Accordingly, the meaning of choreography has transformed from referring to a set of protocols or tools used in order 
to produce something predetermined, i.e. a dance, to an open cluster of tools that can be used as a generic capacity for analysis and production..$^{20}$

Betegnelsen post-dans springer ut av konferansen Post-Dance i 2015, og er vanskelig å holde fast som en meningsbærende term. ${ }^{21}$ Betegnelsens fremste verdi ser ut til å være at den fører til en revitalisering av oppmerksomhet på dans og danser som likeverdig med og uavhengig av koreografi og koreograf: «Flere kom tilbake til den spesielle verdien av å investere tid i en ferdighet, praksis, dans som en måte å være sammen på, som en måte å erfare verden på og verdiene knyttet til dette. $\rangle^{22}$

Edvardsen betrakter koreografi som en måte å skrive på, komposisjon i rom og med tid. Hun identifiserer seg imidlertid som en utøver, og er følgelig opptatt av å gjore, å skrive eller arbeide fra innsiden. ${ }^{23}$ Med denne tosidige praksisen av å skrive og gjøre, koreografere og utøve har hun primært undersøkt ulike forhold i scenerommet. Der bruker hun rommet som en konvensjon eller et virkemiddel til å stille inn publikums oppmerksomhet. Undersøkelsene går til kjernen i en forestillingssituasjon og hvordan publikum sanser og erfarer den. I Black (2011) og No Title (2014) behandler hun språk og persepsjon. Edvardsen trigger mentale bilder av gjenkjennelige gjenstander, tilstander og hendelser ved å navngi dem som nærværende (Black) eller fraværende (No Title). Scenerommet er åpent bortsett fra Edvardsen som står på scenen og utfører enkle, fysiske handlinger. I Black fremkaller og plasserer hun objekter i rommet gjennom et repeterende verbalt språk og enkle bevegelser: Table, table, table, table, table, table, table, table. Chair, chair, chair, chair, chair, chair, chair, chair. I No Title er øvelsen det motsatte; hun erklærer ting for borte og forbi, gone, et ord hun gjentar i løpet av forestillingen for å markere det fysiske fraværet av det som omtales. For å la språkets evne til å påvirke persepsjon tre frem for publikum, underordner Edvardsen betydningen av synssansen. I No Title dekker hun til og med øynene sine med papirbiter med påtegnede bilder av vidåpne øyne. Et lite grep som rykker i opplevelsen av forestillingen, og forteller meg, som publikum, at her er det en annen logikk som rår. Skillet mellom scenen og salen bruker Edvardsen aktivt til å rette oppmerksomhet på konvensjonene og forventningene som er innskrevet i scenerommet. Ved å omskrive disse inviterer hun publikum til å skifte perspektiv og se på nytt.

I scenerommet kommer Edvardsens evne til å stimulere og utfordre publikums forestillingsevne og forventninger tydelig frem. Med Time has fallen asleep in the afternoon sunshine beveger hun seg utenfor scenerommet og dets konvensjoner. Praksisen med å undersøke rommets performative potensial er likevel til stede, men nå er den overført til et annet rom og en annen situasjon. Dette skiller seg fra mye av Edvardsens kunstproduksjon. Samtidig knytter dette prosjektet an til utforskingen av språk og tekst samt ulike medier og materielle forhold som også preger hennes virke. Undersøkelsen av språk og tekst som en del av en utøvende og koreografisk praksis, har kommet til uttrykk i sceneforestillinger, slike som Black, No Title, We to be (2015) og oslo (2017). I every now and then (2009) laget hun og samarbeidspartneren Philippe Beloul en bok som var ment å fungere som en parallell forestilling til sceneforestillingen.

Denne måten å produsere innenfor flere medier på plukker Edvardsen opp igjen i Time has fallen asleep in the afternoon sunshine og We to be. Dette er prosjekter som eksisterer gjennom ulike medier og materialiteter, men konseptuelt sett hører alt til et og samme verk. Som gjenstand har bøker og hefter en materiell tilstand som skiller seg fra den flyktige materialiteten til en forestilling eller en 
lesning. Disse elementene deler forestillingens tid siden de er en medskapende del av den. Samtidig innehar slike gjenstander materielle egenskaper med en annen type varighet enn den sceniske forestillingen. Kanskje kan det sies at de materielle elementene skaper et etterliv for den utøvende situasjonen.

Når Edvardsen introduserer andre varigheter, materielle og romlige forhold til en produksjon, endrer hun betingelsene for persepsjon, og fremhever en mulig spenning mellom erfaringen til den individuelle tilskueren og det kollektive publikummet. Dette er særlig fremtredende i $W e$ to be, en scenisk forestilling som også er direktesendt på nettradio. I scenerommet sitter Edvardsen sammen med publikum. De vender seg mot en tilsynelatende tom scene. Etter hvert fylles scenen av lysspill, synsbedrag og bildene som oppstår i tilskuernes sinn, mens Edvardsen fremfører en tekst. Etter forestillingen blir teksten utdelt som en trykksak. Lyttere til radiosendingen og publikum i salen får ikke tilgang til forestillingen på samme måte, verken estetisk eller dramaturgisk. De er atskilt i rom, og presenteres for situasjoner som krever sanselig oppmerksomhet på ulikt vis. Både radiolytteren og teaterpublikummet må forholde seg til sin egen forestillingsevne. Radiolytteren må i tillegg ta stilling til om hun trenger å bry seg om at det skjer noe i et scenerom et sted. Og betyr det noe for publikum i salen at forestillingen sendes på radio? At det kanskje finnes lyttere der ute? Er radiosendingen og sceneforestillingen fullverdige kunstopplevelser, eller må de betraktes som deler av noe større? Gir rommenes mediespesifikke konvensjoner nok av et holdepunkt til å forstå hva som skjer, eller trenger man en større kontekst for å nærme seg en slik produksjon?

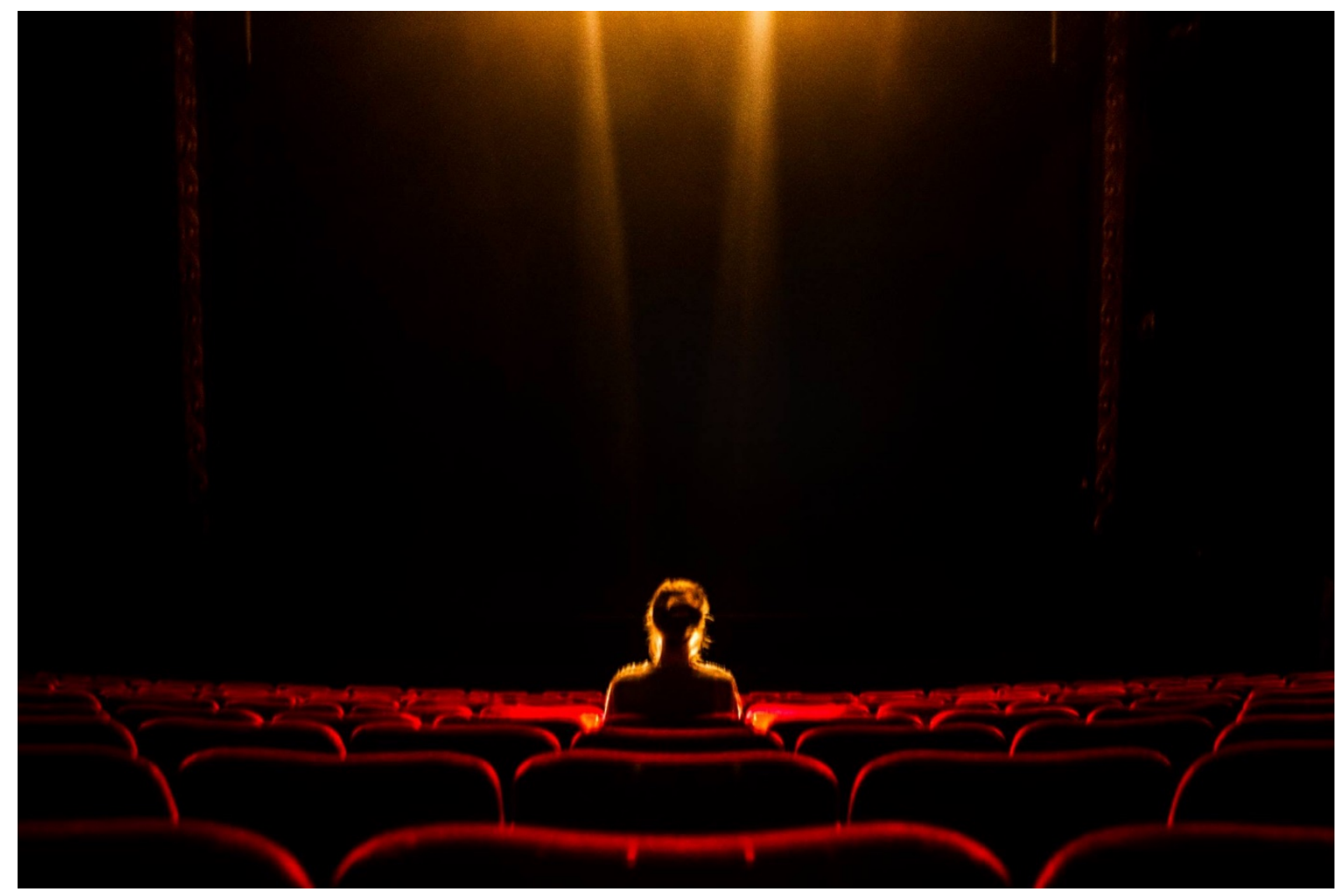

Figur 2. We to be av Mette Edvardsen. Foto: Jan Lietaert Vindevogel 
We to be ble anmeldt på Scenekunst.no utelukkende på bakgrunn av radiosendingen, som attpåtil var tatt opp for at anmelderen kunne høre på den senere, etter at direktesendingen var ferdig. ${ }^{24}$ Dette utløste en debatt om hvilke forventninger kritikere har med seg i møte med et kunstverk. ${ }^{25}$ Spørsmålene debatten reiser, må jeg la ligge her. Denne hendelsen fungerer imidlertid som et eksempel på hvordan ulike medier og formater kan fremprovosere spesifikke forventninger, også når de konseptuelt og kontekstuelt sett hører til det samme kunstverket. We to be eksisterer gjennom flere medier - scenerom, skrift og radiosending - og utfordrer oppfatningen av hva som hører til kunstverket. Med tanke på Jacksons idé om en utveksling mellom kunstuttrykket og publikummet, viser We to be og den påfølgende debatten at opplevelsen av kunstverket formes et sted mellom de kunstneriske premissene og tilskuerens forventninger.

\section{Tvetydighetens estetikk}

I media er det blitt kjent at kunstneren Morten Traavik reiser til Nord-Korea sammen med 19 andre kunstnere for lage (sic) «festspill» på Norges nasjonaldag. Denne turen er finansiert blant annet med midler fra kulturrådet (sic). NK er det mest brutale og hensynsløse regimet verden har sett på lang tid. Fri presse eksisterer ikke og all erfaring tilsier at et slikt «festspill» vil bli utnyttet kynisk i landets massepropaganda.

Synes statsråden det er helt greit at midler fra kulturrådet (sic) legger grunnlag for massepropaganda i Nord-Korea? ${ }^{26}$

Dette spørsmålet fra stortingsrepresentant Gjermund Hagesæter (FrP) var startskuddet for en utveksling gjennom Stortingets skriftlige spørsmål og svar, mellom representant Hagesæter og henholdsvis kulturminister Anniken Huitfeldt (Ap) og utenriksminister Jonas Gahr Støre (Ap) i mai 2012. Hagesæters spørsmål handler om hvorvidt midlene til Den norske stat bør brukes til å støtte Traaviks kunstneriske arbeid i Nord-Korea, og med nordkoreanske aktører som han inviterer til Norge. Helt konkret dreier saken seg om Yes, We Love This Country! - 17. maifestspillene $i$ Nord-Korea (2012), en iscenesatt konsert og en fotoutstilling som gled inn i en prosjektrekke Traavik utførte i Nord-Korea og i Norge i tidsrommet 2010-2017. ${ }^{27}$ Det gjelder midler som ble bevilget over reisestøtteordningen som forvaltes av Danse- og teatersentrum på vegne av Utenriksdepartementet, og støtteordninger i Norsk kulturfond som forvaltes av Norsk kulturråd. Siden disse støtteordningene er avhengige av at midler settes av i statsbudsjettet til deres respektive forvaltere, synes Hagesæter å mene at bevilgningene er en slags forlengelse av Staten og dens politikk. Eller, i en mildere tolkning, at bevilgningene står implisitt i fare for å bli oppfattet slikt. Her er det, ifølge Hagesæter, snakk om et kunstprosjekt i «det mest brutale og hensynsløse regimet verden har sett på lang tid», og som «vil bli utnyttet kynisk i landets massepropaganda». ${ }^{28}$ Dette må de ansvarlige statsrådene svare for, mente han. Og det gjorde de, om enn på ulikt vis.

Mens kulturminister Huitfeldt viser i sine svar til prinsippet om armlengdes avstand mellom politiske myndigheter og Kulturrådets utøvelse av kunstfaglig skjønn og slår fast at Kulturrådets avgjørelser ikke skal overstyres politisk ${ }^{29}$, er utenriksminister Støre rundere i formuleringen og tilsynelatende mer defensiv. Først kritiserer han Traaviks bruk av Utenriksdepartementets logo i informasjonsmateriell om prosjektet. ${ }^{30}$ Selv om Støre sørger for å etablere mest mulig avstand 
mellom Utenriksdepartementet og Traaviks prosjekt, vedgår han at et slikt prosjekt ikke er ulovlig. I et senere svar bidrar han likevel til å slå tvil om prosjektet og samtidig understreke Utenriksdepartementets avstandstagen, ved å antyde at Traavik kan ha brutt bevilgningens vilkår ved å endre innholdet i prosjektet. ${ }^{31}$ Traavik rapporterer til Danse- og teatersentrum som forvalter reisestøtten på vegne av Utenriksdepartementet, påpeker Støre. Han må stå til ansvar, resonnerer Støre, dersom det medfører riktighet at prosjektet ikke ble gjennomført i tråd med innholdet i søknaden.

Selv arbeidet jeg i Kulturrådet i denne perioden. Å redegjøre for bevilgninger til Traavik var til tider nærmest en rutinemessig del av arbeidsoppgavene i stillingen som scenekunstkonsulent. Helt siden Miss Landmine Angola (2005) har Traaviks arbeid skapt kontroverser, også internt i Kulturrådet. Saken om Miss Landmine Kambodsja (2007-2010) er det tydeligste eksemplet på en slik kunstintern kontrovers som oppsto i Kulturrådet, og er konsist oppsummert av Alfred Fidjestøl i boken Eit eige rom som ble utgitt i forbindelse med femtiårsjubileet til Norsk kulturråd. ${ }^{32} \mathrm{I}$ Miss Landmine-prosjektene bruker Traavik skjønnhetskonkurransen som form og begivenhet for å rette oppmerksomhet på ofrene av landminer og utfordre hvilke bilder av utviklingsland vestlige land opererer med. Kvinnelige landmineofre kunne stille i konkurransen som fungerte på samme måte som skjønnhetskonkurranser flest. Premien skulle være en benprotese.

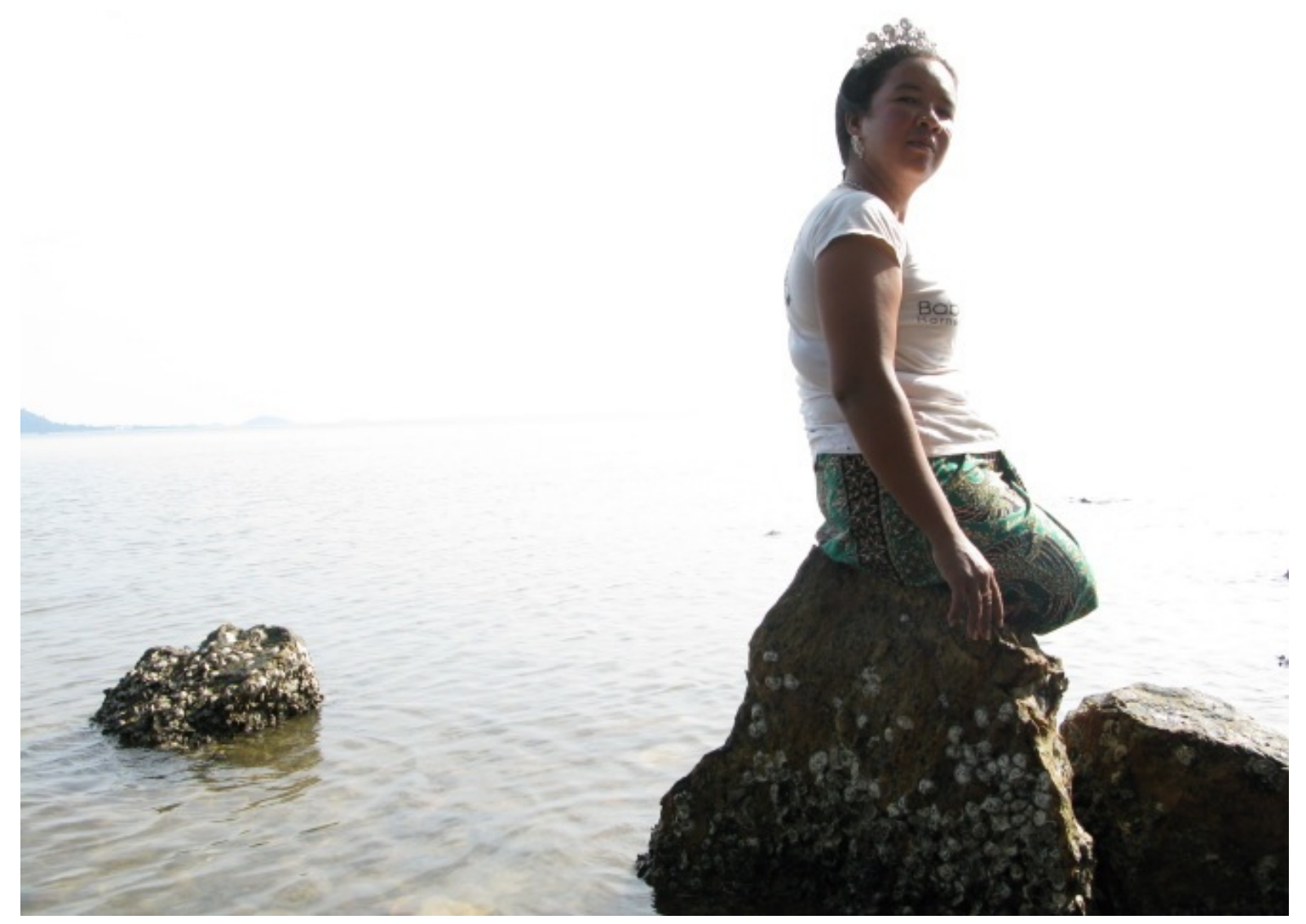

Figur 3. Miss Landmine Kambodsja av Morten Traavik. Foto: Gorm K. Gaare 
Traavik skapte Miss Landmine i Angola med produksjonstilskudd fra Norsk kulturfond. Senere søkte han produksjonstilskudd til å realisere prosjektet med landmineofre i Kambodsja, og Faglig utvalg for scenekunst tilrådte støtte til dette prosjektet også. Men da saken ble lagt frem for Rådet, ble fagutvalget overprøvd og søknaden avslått. Begrunnelsen til Rådet var at prosjektet manglet fornyelse, og var å forstå som en gjentakelse av prosjektet i Angola. ${ }^{33}$ Avslaget skapte offentlig debatt blant annet rundt Rådets kunstsyn. Debattantene, inkludert medlemmer av fagutvalget, mente at Rådet, ved å avslå Miss Landmine Kambodsja, ikke tok hensyn til kunstprosjektets konseptuelle og relasjonelle karakter. ${ }^{34}$

\section{Sammenstøt mellom estetikk og etikk}

Som konsept er Miss Landmine interessant for hvordan det synliggjør produksjonenes avhengighet av å fungere både på kunstneriske premisser og på grunnlag av virkningene de genererer i samfunnet. Det vil si hvordan Miss Landmine blir lest både som kunst og som en skjønnhetskonkurranse, og hvordan disse lesingene er farget av oppfatninger om de kulturelle og samfunnsmessige kontekstene i vestlige og ikke-vestlige land, i dette tilfellet Norge, Angola og Kambodsja. Denne gjensidige avhengigheten mellom kunst og omverden synes å være et vedvarende trekk ved Traaviks kunstnerskap. Traavik kan selv sies å gjøre nytte av denne flertydigheten i et utsagn som dette, med hensyn til Miss Landmine: «Jeg tror at det kun er med vestlige øyne at dette kan leses som et kunstverk - der nede er en skjønnhetskonkurranse en skjønnhetskonkurranse..1 ${ }^{35}$

Traaviks kunstneriske praksis identifiserer og dyrker friksjonsflatene mellom kunstneriske og sosiale virkeligheter. Slike sammenstøt genererer en strøm av virkninger. Denne holdningen gjennomsyrer de estetiske og dramaturgiske tilnærmingsmåtene han anvender, og kan oppsummeres gjennom hans bruk av betegnelsen hyperteater. Traavik forklarer det best selv:

Hypertheatre is happening both within and outside above mentioned arty-ficial boundaries simultaneously, in the multi-layered geographical, cultural, moral and political grey zones that make up the world as we know it. Rather than preparing, directing and/or editing an already 'finished' script or idea within the comfort zone of established art forums, Hypertheatre transplants that creative process into a different social, political, cultural environment and incorporates the synergy and friction between the original concept and the realization of it. Where, for example, contemporary stage theatre (at its best) can be likened to a laboratory, hypertheatre is field work. ${ }^{36}$

Traavik plasserer sin praksis bevisst ute i det han beskriver som de mange lag av geografiske, kulturelle, moralske og politiske gråsoner som utgjør verdenen, slik vi kjenner den. Viljen til å forlate den tilsynelatende trygge, definerende innrammingen en scene eller et galleri kan gi et kunstverk, fremstiller han som nødvendig for å koble seg på energiene som finnes i den sosiale verdenen. Dette er en forutsetning for å kunne gripe inn i eller agere i og med omverdenen. Traavik gjør mer enn å søke å tematisere politiske og moralske problemstillinger gjennom kunstnerisk arbeid. Han lar problemstillingene utspille seg eller levendegjøres gjennom kunstneriske virkemidler og overraskende sammenstillinger, i møte med kontekster der problemstillingene har sitt utspring. Estetisk og dramaturgisk brukes det ofte en form for 
iscenesettelse som spiller på, tar opp i seg, forsterker eller underliggjør aspekter ved kontekstene eller situasjonene som behandles.

Hva skjer når kunstens virkelighetsskapende kapasitet er avhengig av eksisterende virkeligheter? En utøver i Traaviks kunstneriske arbeid er bare tidvis en trent utøver eller profesjonell kunstner. Utøverne er ofte mennesker som lever sine liv eller utfører sitt virke i de spesifikke realitetene Traavik ønsker å behandle. I Miss Landmine er deltakerne i skjønnhetskonkurransen/ kunstprosjektet faktiske landmineofre i Angola og Kambodsja. I prosjektene han har utviklet i samarbeid eller dialog med nordkoreanske aktører, har utøverne eksempelvis vært elever fra musikkskolen Kum Song i Pyongyang, Steinerskolen Ila i Trondheim (Work in Progress, Bastardfestivalen/ Teaterhuset Avant Garden i Trondheim, 2013) og norske soldater fra Garnisonen i Sør-Varanger (The Promised Land, Barents Spektakel i Kirkenes, 2012). ${ }^{37}$ Hvem er disse utøverne når de trer inn $\mathrm{i}$ kunstens sammenheng?

I gråsonene Traavik opererer i, kan det være fristende å søke klarhet. Publikum til et prosjekt vil vekte ulikt de estetiske, geografiske, politiske, sosiale og økonomiske forholdene prosjektet eksempelvis berører eller aktiverer. Ofte spiller eller handler utøveren som en versjon av seg selv innenfor kunstprosjektets synlige og usynlige rammer. Forholdet mellom hvem utøveren forstås til å være utenfor kunstens virkelighet, og hvordan denne identiteten relaterer seg til fortellinger, handlinger og omgivelser innenfor kunstens virkelighet, er en vesentlig faktor i å trigge publikums kritiske refleksjon og fremprovosere både estetiske opplevelser og etiske oppfatninger.

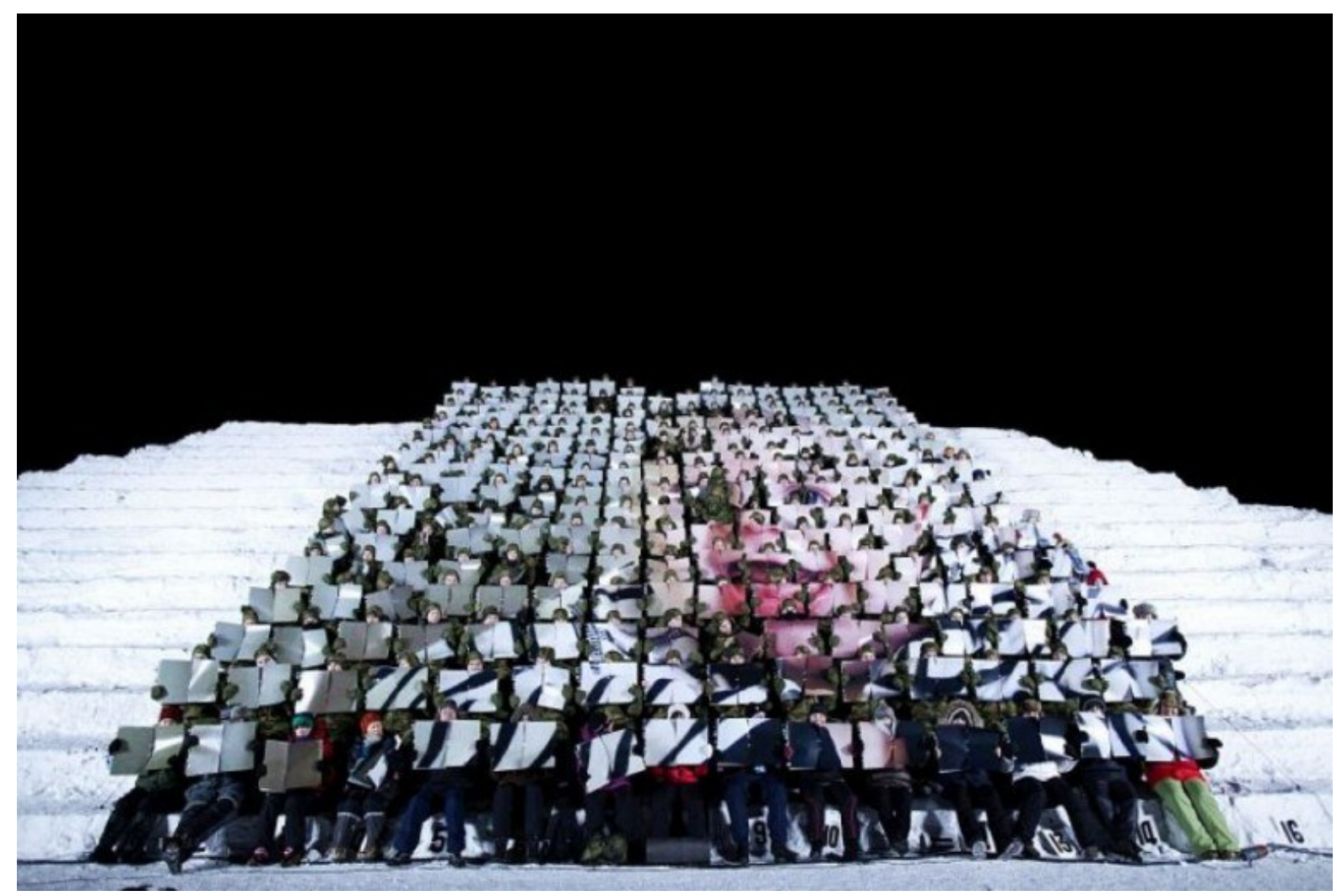

Figur 4. The Promised Land av Morten Traavik. Foto: Bernt Nilsen 
Traaviks tvetydighetsskapende tilnærmingsmåter utsetter prosjektene for spørsmål om etikk og moral. Er det forsvarlig å arbeide med mennesker som er i sårbare situasjoner, slik landmineofrene kan sies å være? ${ }^{38}$ Vil prosjektet ha en positiv effekt på dem og deres livssituasjon, vil det bidra til å kaste lys på en viktig humanitær sak, eller er det en form for utnyttelse som utelukkende tjener den hvite, vestlige, mannlige kunstneren ${ }^{39}$ Er det forsvarlig å arbeide med mennesker som kanskje ikke skjønner fullt ut den kunstneriske og politiske konteksten de medvirker i, slik en kritiker lurte på om var tilfellet for de norske og nordkoreanske ungdommene i Work in Progress? ${ }^{40}$ Ble de norske soldatene i The Promised Land villedet til å delta i et prosjekt som forherliger et utenlandsk regime? ${ }^{41} \mathrm{Og}$ hva med kunstneren selv? Står han og kunsten hans i fare for å bli talerør for nordkoreansk propaganda, slik representant Hagesæter antyder i spørsmålet til kulturministeren? ${ }^{42}$

\section{Medienes performative bidrag}

Tittelen på Morten Traaviks kunstneriske manifest oppsummerer gråsonens problematikk: «To be in it but not of it». ${ }^{43}$ Kunsten - og kunstneren - plasserer seg innenfor situasjonen, men understreker samtidig at den kommer utenfra og er på et vis fortsatt utenfor. Likevel er dette en kunstnerisk praksis der man skal skitne til hendene og arbeide både innenfra og i samarbeid eller forhandling med de rådende maktstrukturene. ${ }^{44}$ Denne holdningen er med på å forklare hvorfor arbeidet til Traavik genererer spørsmål om hvordan utøvende kunst behandler eller går inn $\mathrm{i}$ politiske og sosiale problemstillinger og situasjoner, og hvordan disse forholdene virker tilbake på kunsten. Mediedekningen av kunstnerskapet - både enkeltarbeider og Traaviks arbeidsmåte - har bidratt til å formulere og formidle både usikkerhet og forargelse over hvilke problemstillinger og situasjoner kunstneren ufortrødent velger å ta opp og bokstavelig talt arbeide innenfor, og hvem han inviterer til å medvirke i dette arbeidet. Som teaterviter Julie Rongved Amundsen treffende formulerer det, er mediedekningen fylt med spørsmål av typen «Hva vil Morten Traavik?». ${ }^{45}$ Isteden å gå i møte med hvordan prosjektene fungerer som performative uttrykk, påpeker Amundsen hvordan kritikken som fremstilles gjennom mediene dveler ved politiske og moralske spørsmål om kunstnerens motiver.

Mediedekningen er også med på å forlenge prosjektenes virkning og utgjør i så måte et eget performativt bidrag. Traavik bruker mediene flittig til å generere ikke bare oppmerksomhet på arbeidet, men nye momenter, lesinger og ytringer som inkorporeres i og gir næring til kunstprosjektets videre utvikling. Kritiske stemmer og opponenter gjøres om til ufrivillige medvirkende. De mange direkte og indirekte utvekslingene mellom Traavik og historiker Bård Larsen i forbindelse med Nord-Korea-prosjektene, er et treffende eksempel på hvordan mediene blir enda en scene for Traavik å arbeide på. ${ }^{46}$

Mediebruken til Traavik har også en viktig selviscenesettende funksjon. Som Amundsen ${ }^{47}$ påpeker, er Traaviks egne utsagn egnet til å fyre opp debatten ved å skape usikkerhet rundt hvilke motiver og meninger han selv har. I et journalistisk perspektiv kan en slik fremtreden sies å svekke talerens troverdighet. Det stiller seg imidlertid annerledes i et kunstnerisk perspektiv. Der er tvetydigheten helt i tråd med det femte bud i manifestet til Traavik: 
Hypertheatre does not take sides. It insists on doubt, paradoxes, self-contradictions, inner tensions and polyphony of message(s). Even more so as these are the (only!) badges of honour clearly distinguishing Art from its parasites Politics, Entertainment, Politics and Propaganda (whenever that disctinction (sic) is needed). ${ }^{48}$

Samtidig som Traavik insisterer på forskjellen mellom kunsten og dens «parasitten», plasserer han kunstpraksisen sin eksplisitt i de dunkle sonene mellom geografiske, kulturelle, moralske og politiske forhold hvor skillelinjene er vanskelig å trekke. Ved å betrakte kunstens konvensjonelle rom (teatre, gallerier) som en kunstig avgrensing av det iscenesatte, og isteden gjøre krav på verdenen utenfor, demonterer Traavik den gjenkjennelige innrammingen som holder det kunstneriske uttrykket på plass. Han utsetter kunsten for den uforutsigbare omverdenen hvor andre mennesker, mekanismer og medieringer rår, men hvor de samme menneskene, mekanismene og mediene samtidig er tilgjengelig for kunstnerens bruk. I en slik kunstpraksis er publikums posisjon ustabil og foranderlig; man kan oppleve å være betraktende, deltakende, samhandlende eller på annet vis implisert i et prosjekt og de flertydige, medierte virkelighetene det skaper.

Traavik bruker kun tidvis den arkitektoniske teaterscenen som en fysisk og meningsbærende ramme for det kunstneriske arbeidet. Det er påfallende hvordan Traavik ikke pleier å gjenoppta de sceniske forestillingene, selv om de i prinsippet kan vises flere ganger. Om dette er tilsiktet eller utilsiktet, vet jeg ikke. Når det gjelder de uforutsigbare samarbeidene i Nord-Korea, kan det tenkes at en del av grunnen kan være krevende logistikk. Samtidig bidrar sceneforestillingenes forgjengelighet til å understreke den aktivistiske og intervenerende karakteren ved Traaviks kunstneriske virke. Kunsten skal gripe inn i samfunnsforhold, og en sceneforestilling kan være et strategisk valg for å tilkalle en bestemt type oppmerksomhet eller fremvise et bestemt bilde av verdenen. I Traaviks kunstnerskap er det vanskelig å isolere en scenisk manifestasjon fra den kunstneriske praksisen som genererer den sammen med andre handlinger og ytringer, eller fra den sosiale virkeligheten forestillingen allerede har tatt opp i seg og fortsetter å virke i. Konteksten og kunstverket er uatskillelig men likevel ikke det samme. Utenfor scenen overtar medienes performativitet for scenens performativitet. Utspillene i mediene og dekningen av disse blir en ny form for produksjon som fører kunsten videre inn i samfunnet hvor nye virkninger oppstår.

\section{Å stille inn publikums oppmerksomhet}

Estetiske og dramaturgiske valg skaper forutsetningene for hvordan scenekunsten virker ved å stille inn publikums oppmerksomhet på bestemte måter og på bestemte forhold. Bevisstheten om det Jackson kaller 'kunstens virkelighetsskapende kapasitet ${ }^{\text {'4 }}$, er en integrert del av et kunstnerisk arbeid som utløses i møte med publikum. Denne artikkelen begynner med sitater av Edvardsen og Traavik, der de reflekterer over hvilke betingelser for resepsjon de har ambisjon om å skape gjennom sitt virke. ${ }^{50}$ Ordene deres blir nesten som et konsentrat av sentrale trekk ved kunstnerskapene. Edvardsen trekker frem betydningen av publikums forestillingsevne, og speiler på den måten hvordan kunsten hennes tiltaler publikums sanseapparat og innbyr til å iaktta verdenen på nye måter. Traavik uttaler seg tvetydig, og antyder derved at kunstens kraft ligger i det uavklarte forholdet mellom det autonome og det heteronome, eller «ren kunst» og «politisk 
performance» for å bruke formuleringen hans. Edvardsen og Traavik står frem for meg som eksempler på kunstnere som stiller grunnleggende spørsmål om scenekunstens betingelser og muligheter i møte med omverdenen. På hvert sitt vis dytter de på publikums forventninger. Edvardsen gjør det med dansens og koreografiens fortegn, Traavik med teatrets. 


\section{Noter}

${ }^{1}$ Sortland, «Store spørsmål, enkle virkemidler».

2 Revheim, «Traavik vil utfordre verden».

${ }^{3}$ I sitt bidrag til denne utgivelsen viser Siemke Böhnisch på en utmerket måte behovet for kontekst- og verksspesifikke analyser ved å ta utgangspunkt i hendelsene 22. juli 2011 og forestillingene Breiviks Erklärung og Manifest 2083. Böhnisch, «Scenekunstens (for)handlingsrom etter 22. juli», 3-19.

${ }^{4}$ Røssland, «Norsk scenekunst henges ut på nett: - Jeg mottar ikke 1,9 millioner i lønn fra Kulturrådet».

${ }^{5}$ Se for eksempel Trulsen, «Omstridt Nord-Korea-kunstner får over ti millioner i statsstøtte». I sluttfasen av arbeidet med denne artikkelen oppsto en heftig og i skrivende stund pågående debatt om forestillingen Ways of Seeing av Pia Maria Roll, Hanan Benammer, Sara Baban og Marius von der Fehr, som ble vist på Black Box teater 21.-30. november 2018. I denne debatten har den verdimessige og kulturpolitiske kritikken av både forestillingen og teatret fått stort fokus, mens forsøk på å beskrive og analysere hvordan forestillingen og dens virkemidler nettopp virker, ser ut til å få mindre plass. For en kort oppsummering og kommentar til debatten se Amundsen, «Måter å se på».

${ }^{6}$ Metteedvardsen.be, «Biography».

7 Traavik.info, «Supervision».

${ }^{8}$ Kristian Meisingset beskriver på en interessant måte hvordan kunst, politikk og ideologi veves sammen både i kunstuttrykk, kunstneriske vurderinger og det offentlige ordskiftet om kunst. Meisingset, «Narrer Nord-Korea».

${ }^{9}$ Christoffersen et al., «Redaksjonelt forord», 3 .

${ }^{10}$ Graffer og Sekkelsten, «Introduksjon», 11.

${ }^{11}$ Nagel, Kunst for barn som hendelser, 84-85.

${ }^{12}$ Saur, «Autentisk eller nyskapende?», 291.

${ }^{13}$ Kvalbein, «Ultima: autonomi på spel - mellom gründarmakt og kuratormakt», 258-261.

${ }^{14}$ Jackson, «Performativity and Its Addressee».

15 Time Out London, «Time has fallen asleep in the afternoon sunshine».

${ }^{16}$ De Wachter, «The match / in accordance with orders / communicated burning».

${ }_{17}$ Royo, «Real Fictions: Time has fallen asleep in the afternoon sunshine».

${ }^{18}$ Edvardsen, I Am a Cat by Soseki Natsume.

${ }^{19}$ Kunstenfestivaldesarts, «Second Generation».

${ }^{20}$ Spångberg et al. sitert i Sabisch, «For a Topology of Practices», 73.

${ }^{21}$ Andersson et al., Post-Dance.

${ }^{22}$ Hall, «Postdance: En danserisk reorientering», 74.

${ }^{23}$ Sortland, «Store spørsmål, enkle virkemidlen».

${ }^{24}$ Borge, «Konkyliens brus».

${ }^{25}$ Nordvåg, «Referat: Dans, estetikk og kritikk».

${ }^{26}$ Stortinget, «Skriftlig spørsmål fra Gjermund Hagesæter (FrP) til kulturministeren», dokument nr. 15:1415.

${ }_{27}$ Ibid., dokument nr. 15:1415 og 15:1473; Stortinget, «Skriftlig spørsmål fra Gjermund Hagesæter (FrP) til utenriksministeren», dokument nr. 15:1416 og 15:1474. 
${ }^{28}$ Stortinget, «Skriftlig spørsmål fra Gjermund Hagesæter (FrP) til kulturministeren», dokument nr. 15:1415; Stortinget, «Skriftlig spørsmål fra Gjermund Hagesæter (FrP) til utenriksministeren», dokument nr. 15:1416.

${ }^{29}$ Stortinget, «Skriftlig spørsmål fra Gjermund Hagesæter (FrP) til kulturministeren», dokument nr. 15:1415 og 15:1473.

${ }^{30}$ Stortinget, «Skriftlig spørsmål fra Gjermund Hagesæter (FrP) til utenriksministeren», dokument nr. 15:1416.

${ }^{31}$ Stortinget, «Skriftlig spørsmål fra Gjermund Hagesæter (FrP) til utenriksministeren», dokument nr. $15: 1474$.

32 Fidjestøl, Eit eige rom, 285-288.

33 Ibid., 286.

${ }^{34}$ Ibid., 285-288.

${ }^{35}$ Lindgren, «Etisk minefelt».

${ }^{36}$ Traavik, «Manifesto. To be in it but not of it. A ten point (sic) hypertheatre manifesto in progress».

37 Traavik.info, «W.I.P.»; «The Promised Land».

38 MacKinnon, «Miss Landmine: exploitation or bold publicity for the victims?».

${ }^{39}$ Lindgren, «Etisk minefelt».

${ }^{40}$ Haugland, «En forestilling om forestillinger».

${ }^{41}$ Melgård, «Frp mener norske soldater blir brukt i nordkoreansk propaganda».

42 I 2017 besluttet Traavik å legge samarbeidet med nordkoreanske aktører på is. Bakgrunnen for avgjørelsen var den tilspissede politiske situasjonen og trusler rettet mot kunstneren under hans siste opphold i landet. Se for eksempel Alnes, «Traavik drapstruga i Nord-Korea».

${ }^{43}$ Traavik, «Manifesto. To be in it but not of it. A ten point (sic) hypertheatre manifesto in progress».

${ }^{44}$ Ibid.

45 Amundsen, «Hva vil Morten Traavik?».

${ }^{46}$ Bård Larsen er tilknyttet tankesmien Civita. I forbindelse med at Traavik skulle vise Kardemomyang, en forestilling basert på Thorbjørn Egners Kardemomme by og som fremføres av nordkoreanske barn, på Festspillene i Bergen i 2014, opprettet Civita en hendig liste over saker Larsen og andre har skrevet om Traavik tidligere. Civita, «Traavik, kunst og Nord-Korea».

47 Amundsen, «Hva vil Morten Traavik?».

${ }^{48}$ Traavik, «Manifesto. To be in it but not of it. A ten point (sic) hypertheatre manifesto in progress».

${ }^{49}$ Jackson, «Performativity and Its Addressee».

${ }^{50}$ Sortland, «Store spørsmål, enkle virkemidler»; Revheim, «Traavik vil utfordre verden». 


\section{Bibliografi}

Alnes, Espen. «Traavik drapstruga i Nord-Korea.» Nrk.no. 07.09.2017. [Lest 05.04.2018] https://www.nrk.no/kultur/traavik-drapstruga-i-nord-korea-1.13675331.

Amundsen, Julie Rongved. «Hva vil Morten Traavik?» Scenekunst.no. 20.09.2012. [Lest 05.04.2018] http://www.scenekunst.no/sak/hva-vil-morten-traavik/.

Amundsen, Julie Rongved. «Måter å se på.» Scenekunst.no. 14.12.2018. [Lest 27.12.2018] http://www.scenekunst.no/sak/mater-a-se-pa/.

Andersson, Danjel, Mette Edvardsen og Mårten Spångberg (red.). Post-dance. Stockholm: MDT, 2017.

Borge, Arne. «Konkyliens brus.» Scenekunst.no. 23.10.2015. [Lest 20.03.2018] http://www.scenekunst.no/sak/konkyliens-brus/.

Böhnisch, Siemke. «Scenekunstens (for)handlingsrom etter 22. juli.» Teatervitenskapelige studier Nummer 2 (2019): 3-19. 27.06.2019. DOI 10.15845/tvs.v2i0.2858

Christoffersen, Erik Exe, Janicke Branth, Solveig Gade og Laura Schultz. «Redaksjonelt Forord.» Peripeti: Tidsskrift for dramaturgiske studier, Nr. 8 (2008): 3-4. [Lest 27.12.2018] http://www.peripeti.dk/pdf/peripeti_10_2008.pdf.

Civita. «Traavik, kunst og Nord-Korea.» [Lest 05.04.2018] https://www.civita.no/2014/05/23/traavik-kunst-og-nord-korea.

De Wachter, Bruno. «The match / in accordance with orders / communicated burning», Metteedvardsen.be. [Lest 19.03.2018] http://www.metteedvardsen.be/texts.html.

Edvardsen, Mette. I Am a Cat by Soseki Natsume. Brussel: Time has fallen asleep in the afternoon sunshine, 2017.

Fidjestøl, Alfred. Eit eige rom: Norsk kulturråd 1965-2015. Oslo: Samlaget, 2015.

Graffer, Sidsel og Ådne Sekkelsten. «Introduksjon.» I Scenekunst og de unge, redigert av Sidsel Graffer og Ådne Sekkelsten, 11-15. Oslo: Vidarforlag, 2014.

Hall, Snelle. «Postdance: En danserisk reorientering.» Norsk Sbakespeare- og teatertidsskrift, Nr. 1 (2016): 72-74.

Haugland, Eivind. «En forestilling om forestillinger.» Periskop.no. 16.09.2013. [Lest 05.04.2018] http://www.periskop.no/en-forestilling-om-forestillinger/.

Jackson, Shannon. «Performativity and Its Addressee», Walker Living Collections Catalogue (2014). [Lest 27.03.2018] http://www.walkerart.org/collections/publications/peformativity/performativity-andits-addressee/.

Kunstenfestivaldesarts. «Second Generation.» [Lest 19.03.2018] http://www.kfda.be/en/program/mette-edvardsen. 
Kvalbein, Astrid. «Ultima: autonomi på spel - mellom gründarmakt og kuratormakt.» I Iverksettelse. Fire studier av kunst, autonomi og makt, redigert av Tore Slaatta, 234-270. Oslo: Universitetsforlaget, 2018.

Lindgren, Lena. «Etisk minefelt.» Morgenbladet. 20.01.2006. MacKinnon, Ian. «Miss Landmine: exploitation or bold publicity for the victims?» The Guardian. 22.04.2008. [Lest 05.04.2018] https://www.theguardian.com/world/2008/apr/22/cambodia.internationalaidanddevelo pment.

Meisingset, Kristian. «Narrer Nord-Korea.» Minerva. 18.09.2013. [Lest 13.07.2018] https://www.minervanett.no/narrer-nord-korea/.

Melgård, Marie. «Frp mener norske soldater blir brukt i nordkoreansk propaganda.» Bergens Tidende. 27.02.2012.

Metteedvardsen.be. «Bibliography.» [Lest 19.03.2018] http://www.metteedvardsen.be/bio.html.

Nagel, Lise. Kunst for barn som hendelser: En kritisk diskusjon av analytiske perspektiver $i$ kunst for barn, med eksempler fra scenekunst, bildeboker og bildebokapper. Ph.D. avhandling. Norsk barnebokinstitutt og Universitetet i Oslo. 2018.

Nordvåg, Hanne Bernhardsen. «Referat: Dans, estetikk og kritikk», Kritikerlaget.no. [Lest 27.12.2018] https://www.kritikerlaget.no/saker/referat-dans-estetikk-og-kritikk.

Revheim, Hanna Huglen. «Traavik vil utfordre verden.» Bergens Tidende. 09.05.2012.

Royo, Victoria Pérez. «Real Fictions: Time has fallen asleep in the afternoon sunshine», Metteedvardsen.be. [Lest 19.03.2018] http://www.metteedvardsen.be/texts.html.

Røssland, Marie. «Norsk scenekunst henges ut på nett: - Jeg mottar ikke 1,9 millioner i lønn fra Kulturrådet.» Dagbladet. 05.07.2017. [Lest 13.07.2018]

https://www.dagbladet.no/kultur/norsk-scenekunstner-henges-ut-pa-nett---jeg-mottarikke-19-millioner-i-lonn-fra-kulturradet/68470266.

Sabisch, Petra. «For a Topology of Practices.» I Independent Theatre in Contemporary Europe. Structures, Aesthetics, Cultural Policy, redigert av Manfred Brauneck og ITI Germany, 43184. Bielefeld: Transcript, 2017.

Saur, Ellen. «Autentisk eller nyskapende? Hvordan forstå kvalitet når skuespillere har en utviklingshemming.» I Kvalitetsforbandlinger: Kvalitetsbegrepet i samtidens kunst og kultur, redigert av Jan Fredrik Hovden og Øyvind Prytz, 283-308. Bergen: Fagbokforlaget, 2018.

Sortland, Venke. «Store spørsmål, enkle virkemidler.» Scenekunst.no. 12.10.2015. [Lest 19.03.2018] http://www.scenekunst.no/sak/store-sporsmal-enkle-virkemidler/. Stortinget. «Skriftlig spørsmål fra Gjermund Hagesæter (FrP) til kulturministeren.» Dokument nr. 15:1415 (2011-2012), Innlevert: 16.05.2012, Sendt: 18.05.2012, Besvart: 25.05.2012 av kulturminister Anniken Huitfeldt. [Lest 10.04.2018] https://www.stortinget.no/no/Saker-og-publikasjoner/Sporsmal/Skriftlige-sporsmal-ogsvar/Skriftlig-sporsmal/?qid $=53817$.

Stortinget. «Skriftlig spørsmål fra Gjermund Hagesæter (FrP) til utenriksministeren.» Dokument nr. 15:1416 (2011-2012), Innlevert: 16.05.2012, Sendt: 18.05.2012, Besvart: 22.05.2012 av utenriksminister Jonas Gahr Støre. [Lest 10.04.2018] 
https://www.stortinget.no/no/Saker-og-publikasjoner/Sporsmal/Skriftlige-sporsmal-ogsvar/Skriftlig-sporsmal/?qid=53818.

Stortinget. «Skriftlig spørsmål fra Gjermund Hagesæter (FrP) til kulturministeren.» Dokument nr. 15:1473 (2011-2012), Innlevert: 29.05.2012, Sendt: 30.05.2012, Besvart: 05.06.2012 av kulturminister Anniken Huitfeldt. [Lest 10.04.2018] https://www.stortinget.no/no/Saker-og-publikasjoner/Sporsmal/Skriftlige-sporsmal-ogsvar/Skriftlig-sporsmal/?qid=53904.

Stortinget. «Skriftlig spørsmål fra Gjermund Hagesæter ( $\mathrm{FrP}$ ) til utenriksministeren.» Dokument nr. 15:1474 (2011-2012), Innsendt: 29.05.2012, Sendt: 30.05.2012, Besvart: 04.06.2012 av utenriksminister Jonas Gahr Støre. [Lest 10.04.2018]

https://www.stortinget.no/no/Saker-og-publikasjoner/Sporsmal/Skriftlige-sporsmal-ogsvar/Skriftlig-sporsmal/?qid=53906.

Time Out London. «Time has fallen asleep in the afternoon sunshine.» [Lest 19.03.2018] https://www.timeout.com/london/dance/time-has-fallen-asleep-in-the-afternoonsunshine.

Trulsen, Ola Nymo. «Omstridt Nord-Korea-kunstner får over ti millioner i statsstøtte.» Nrk.no. 19.03.2015. [Lest 13.07.2018] https:/ /www.nrk.no/kultur/omstridt-nord-korea-kunstnerfar-10 5-millioner-1.12269074.

Traavik, Morten. «Manifesto. To be in it but not of it. A ten point (sic) hypertheatre manifesto in progress», Traavik.info. [Lest 27.03.2018] http://www.traavik.info/manifesto/.

Traavik.info. «Supervision.» [Lest 27.03.2018] http://www.traavik.info/organisation/mortentraavik.

Traavik.info. «The Promised Land.» [Lest 05.04.2018] http://www.traavik.info/works/thepromised-land.

Traavik.info. «W.I.P.» [Lest 05.04.2018] http://www.traavik.info/works/work-in-progress. 